\title{
Financing the development of the regional vocational training system: qualitative changes
}

\author{
Elena Dvoryadkina, Elena Efimova, Dina Prostova \\ Ural State University of Economics, 62/45 8 Marta/Narodnoy Voli St., Ekaterinburg, 620144, Russia
}

\begin{abstract}
Innovative development of the national economy is Russia's main strategic aim in a globally competitive environment. In general, innovation processes should start with transformations within regions, as it is the regions in Russia that form the basis of the national economic system. The purpose of this paper is to identify prospective directions for qualitative changes in the development of the regional vocational education system, which is the object of the study. The authors focus on the financing of regional vocational education system development, since this system is considered one of the most important factors of economic competitiveness, national security, and at the same time, vocational training is the basis for human capital accumulation and development. Regional programs, which are one of the instruments for financing education systems at regional level, are analyzed.
\end{abstract}

\section{Introduction}

The effective functioning of the national economy in today's environment requires a transition to an innovative path of development. The strategy of innovative modernization of the Russian economy puts the development of the vocational education system in the country's regions at the forefront. Education is among the most important factors of national security and serves as the basis for the accumulation and development of human capital in the emerging post-industrial society. In general, the regional vocational education system acts as a factor of regional economic development and competitiveness [1] and it is a component of the regional socio-economic system.

The functioning of vocational education systems at the regional level is considered in the works of A.A. Tonzherakova [2], G.N. Lishchina [3], D.G. Setalov [4], V.V. Miroshnichenko. 5], Dmitriev N.A. and Konstantinova L.A. [6], Lapushinskaya G.K. [7]. Summarizing the definitions of the concept of regional system of professional education, presented in the works of the abovementioned scientists, we formulate the author's definition: regional system of professional education is a set of educational organizations, implementing programs of basic and additional professional education and vocational training, functioning in the socio-economic space of the region and territorially localized in municipalities, whose activities are aimed at forms [8].

\section{Legal and regulatory methods in the development of the regional vocational education system and its financing}


At present, Russia has developed legislative documents at the federal level containing guidelines for the development of the vocational education sector:

- State Program of the Russian Federation "Development of Education" [9];

- Federal Law of 29.12.2012 No. 273-FZ "On Education in the Russian Federation";

- Presidential decrees of May 7, 2012, No. 597 On measures to implement state social policy and No. 599 On measures to implement state policy in education and science;

- Strategy for the Development of the System of Training of Workers and the Formation of Applied Qualifications in the Russian Federation for the period until 2020 [10];

- A set of measures aimed at improving the vocational training system for 2015-2020 [11];

- National Security Strategy of the Russian Federation [12].

An important document defining the main directions for modernizing the education system is the state program of the Russian Federation "Development of Education". The new program (until 2025) identifies three most important strategic orientations for this period: 1) quality of education; 2) accessibility of education; and 3) online education.

These guidelines continue the main goal of the previous state program until 2020: "creating conditions for effective development of Russian education...", where attention was paid to "creating infrastructure that ensures conditions for training personnel for modern economy, formation of in-demand system of education quality assessment and educational results" [13].

The new State Program "Development of Education" until 2025 contains important directions for modernizing the education system, including the sub-program "Implementing educational programs for vocational training" with a set of projects aimed at creating a modern digital educational environment, training highly qualified specialists and workers in demand in the new economic conditions, and developing universities as innovation centers and sites for cooperation with industrial enterprises. The training of highly qualified specialists, including scientific personnel, for the development of a knowledge-based, digital economy is a priority [14], where the training system is one of the priority national interests (science, technology and education) in ensuring national security $[15,16]$.

As part of government policy on the development of vocational education, the Strategy for the development of the system of training workers and the formation of applied qualifications in the Russian Federation until 2020 was developed, where specific targets and indicators were formulated, which aimed at increasing the proportion of graduates of vocational educational organizations who were employed in their specialty; increasing the share of coverage of the population with programs of additional vocational education and vocational training / retraining; an increase in the share of constituent entities of the Russian Federation participating in the WorldSkills Russia movement and etc.

The development of the education system, including vocational training, is reflected in the Strategy for Innovative Development of the Russian Federation for the period until 2020 [17], where the innovative way of development of the state economy is impossible without modernization of education and science, and innovation is one of the strategic guidelines of state policy.

For the period 2021-2030 it is envisaged to implement the program of strategic academic leadership (Priority 2030 program) aimed at supporting the development programs of educational institutions of higher education. The instrument for the implementation of this program will be grants in the form of subsidies to support this development program, including those implemented jointly with scientific organizations and providing personnel training for priority directions of scientific and technological development of the Russian Federation [18]. 


\section{Analysis of budget financing in the development of the education system, using the Sverdlovsk region as an example}

Let us describe the budget financing of the Sverdlovsk region's education system using the example of the regional budget (Table 1).

Table 1. Education expenses in the structure of regional budget expenditures in Sverdlovsk Region in 2016-2020, RUB thousand*

\begin{tabular}{|l|c|c|c|c|c|}
\hline \multicolumn{1}{|c|}{ Indicators } & Budget 2016 & Budget 2017 & $\begin{array}{c}\text { Budget } \\
\mathbf{2 0 1 8}\end{array}$ & Budget 2019 & Budget 2020 \\
\hline $\begin{array}{l}\text { Budget } \\
\text { expenditure, total }\end{array}$ & 190941821,2 & 199414792,4 & $\begin{array}{c}22525360 \\
2,6\end{array}$ & 257378074,2 & 296594051,9 \\
\hline $\begin{array}{l}\text { Expenditure under } \\
\text { "Education" }\end{array}$ & 51247253,2 & 53259994,4 & $\begin{array}{c}57861614, \\
4\end{array}$ & 66544292,8 & 75858172,5 \\
\hline Specific weight, \% & 26,8 & 26,7 & 25,7 & 25,9 & 25,6 \\
\hline Including: & & & & & \\
\hline $\begin{array}{l}\text { Pre-school } \\
\text { education }\end{array}$ & 15349489,9 & 15796261,9 & $\begin{array}{c}16160380, \\
4\end{array}$ & 18886282,6 & 20512411,7 \\
\hline Specific weight, \% & 8,0 & 7,9 & 7,2 & 7,3 & 6,9 \\
\hline $\begin{array}{l}\text { General education } \\
\text { Specific weight, \% }\end{array}$ & 14,7 & 14,3 & 14,0 & 13,8 & 13,6 \\
\hline $\begin{array}{l}\text { Additional } \\
\text { education for } \\
\text { children }\end{array}$ & & 767733,5 & 732432,7 & 1576034,8 & 2409446,9 \\
\hline Specific weight, \% & & 0,4 & 0,3 & 0,6 & 0,8 \\
\hline $\begin{array}{l}\text { Secondary } \\
\text { vocational training }\end{array}$ & 5735064,2 & 5729065,7 & 6415924,2 & 7562898,1 & 7649139,4 \\
\hline Specific weight, \% & 3,0 & 2,8 & 2,8 & 2,9 & 2,6 \\
\hline $\begin{array}{l}\text { Vocational } \\
\text { training, retraining } \\
\text { and further training }\end{array}$ & 120095,0 & 94671,2 & 141336,4 & 156159,9 & 318295,2 \\
\hline Specific weight, \% & 0,1 & & & & 0,1 \\
\hline Youth policy & 1226788,9 & 1471687,6 & 1535706,3 & 1947379,2 & 2004135,5 \\
\hline Specific weight, \% & 0,6 & 0,7 & 0,7 & 0,8 & 0,7 \\
\hline $\begin{array}{l}\text { Other educational } \\
\text { issues }\end{array}$ & 850245,7 & 951532,6 & 1342991,2 & 1034650,1 & 2744938,2 \\
\hline $\begin{array}{l}\text { Specific weight, } \\
\text { \% }\end{array}$ & 0,4 & 0,5 & 0,6 & 0,4 & 0,9 \\
\hline
\end{tabular}

A share of expenditures on the section "Education" in the total volume of regional budget expenditures is quite significant, accounting for nearly a third, but declining from $26.8 \%$ to $25.6 \%$ over the period $2016-2020$, with expenditures on pre-school education (by 1.1 percentage point), general education (by 1.1 percentage point) and secondary vocational education (by 0.4 percentage point) falling in terms of specific spending areas.

As the subject of the study is the vocational education system in the region, special attention will be paid to the analysis of budget financing of secondary vocational education and training, retraining and advanced training.

* Table compiled from: On the regional budget for 2020 and planning period 2021-2022: Sverdlovsk Oblast Law of 12.12.2019 No. 120-OZ; On the regional budget for 2019 and planning period 2020-2021: Sverdlovsk Oblast Law of 06.12.2018. No. 144-OZ; On the regional budget for 2018 and the planning period 2019-2020: Law of Sverdlovsk region of 07.12.2017 No. 121-OZ; On the regional budget for 2017 and the planning period 2018-2019: Law of Sverdlovsk region of 19.12.2016 No. 131-OZ; On the regional budget for 2016: Law of Sverdlovsk region of 03.12.2015 No. $138-\mathrm{OZ}$. 
The structure of the network of educational organizations of professional education in Sverdlovsk region in 2019 was represented by professional educational organizations and educational organizations of higher education. According to the Ministry of Education of the Russian Federation (according to the form of federal statistical observation No. SPO-1), at the beginning of the $2019 / 2020$ academic year the network of professional educational organizations in Sverdlovsk Oblast was represented by 129 educational organizations training mid-level specialists [19]. The text of the state programme "Development of the Education System and Implementation of Youth Policy in the Sverdlovsk Region until 2025 " formulates qualitative changes in the system of secondary vocational education in the Sverdlovsk Region. They include:

1) Sverdlovsk region in the top five of the WorldSkills movement;

2) an increase in the total number of students in secondary vocational education programs and demonstrating a level of training that meets WorldSkills standards by 9.4 thousand people;

3) positive dynamics of the average score on the school leaving certificate when applying to technical professions in secondary vocational training organizations;

4) the new type of state final examination, the WorldSkills demonstration examination, is being piloted;

5) creating conditions in the Sverdlovsk Region to train qualified personnel in the most in-demand, new and promising professions and specialties (TOP-50).

It is also noted that the system of secondary vocational training in the Sverdlovsk region is one of the most dynamically developing educational systems in the Russian Federation.

The bodies of State power of the constituent entities of the Russian Federation ensure State guarantees of the right to receive accessible and free secondary vocational education by granting subsidies to vocational educational organizations and educational organizations of higher education under the jurisdiction of the constituent entities of the Russian Federation for financially supporting the performance of the State task or by granting subsidies to private educational organizations to cover the costs of their implementation of programs of secondary vocational training. [20].

It is worth agreeing with the conclusions of other researchers that expenditure on vocational education and training has been increasing in recent years due to the active implementation of government projects and programs to improve the quality and competitiveness of Russian education. The amount of budget funding for the educational services of secondary vocational training institutions is closely linked to the current method of funding: as the number of students decreases, so does the amount of funding [21].

The composition of regional budget expenditure for financing secondary vocational education, vocational training, retraining and professional development in Sverdlovsk Oblast is shown in Table 2.

Table 2. Regional budget expenditures on secondary vocational education, vocational training, retraining and professional development in Sverdlovsk Region in 2016-2020, RUB thousand $\dagger$

\begin{tabular}{|l|c|c|c|c|c|}
\hline \multicolumn{1}{|c|}{ Indicators } & Budget 2016 & Budget 2017 & Budget 2018 & Budget 2019 & Budget 2020 \\
\hline $\begin{array}{l}\text { Secondary vocational } \\
\text { training }\end{array}$ & 5735064,2 & 5729065,7 & 6415924,2 & 7562898,1 & 7649139,4 \\
& & & & &
\end{tabular}

$\dagger$ Table compiled from: On the regional budget for 2020 and planning period 2021-2022: Sverdlovsk Oblast Law of 12.12.2019 No. 120-OZ; On the regional budget for 2019 and planning period 2020-2021: Sverdlovsk Oblast Law of 06.12.2018. No. 144-OZ; On the regional budget for 2018 and planning period 2019-2020: Sverdlovsk Oblast Law of 07.12.2017 No. 121-OZ; On the regional budget for 2017 and planning period 2018-2019: Sverdlovsk Oblast Law of 19.12.2016 No. 131-OZ; On the regional budget for 2016: Sverdlovsk Oblast Law of 03.12.2015 No. 138-OZ. 
Continuation of Table 2

\begin{tabular}{|l|l|l|l|l|l|}
\hline $\begin{array}{l}\text { Vocational training, } \\
\text { retraining and } \\
\text { advanced training }\end{array}$ & 120095,0 & 94671,2 & 141336,4 & 156159,9 & 318295,2 \\
\hline
\end{tabular}

The functional classification of budget expenditures implies their presentation in terms of state programs implemented in the constituent entity of the Russian Federation. The largest spending state program in this area is the Sverdlovsk Region state program "Development of the Education System and Implementation of Youth Policy in the Sverdlovsk Oblast until 2025", which includes several subprograms.

The subprogram "Quality of Education as a Basis for Well-being" has the largest share in the structure of subprogram funding: in $2017,91.4 \%-91.4 \%$, in $2018-89.5 \%, 86.8 \%$ in 2019 , and $86.8 \%$ in $2020-85.0 \%$. The purpose of this subprogram is to ensure the availability of quality education that meets the requirements of innovative socio-economic development of the Sverdlovsk region.

The subprogram "Pedagogical Staff of the 21 st Century" has the following indicators of the share in the structure of financing of the Sverdlovsk Oblast state program "Development of the Education System and Implementation of the Youth Policy in the Sverdlovsk Region until 2025": in 2017. - 8.6\% in 2017, 8.0\% in 2019, and 8.1\% in 2020 $8.1 \%$. This subprogram is aimed at renewing the system for developing teaching staff and raising the prestige of the teaching profession. The bulk of spending on financing the subprogram "Pedagogical Staff of the 21st Century" in 2017-2020 is allocated to the organization of secondary vocational education in state vocational educational institutions implementing teacher education programs.

The Sverdlovsk Region is an industrial region where the Urals Engineering School project is being implemented, which aims to provide conditions for training workers and engineers on a scale and with a quality that meets the current and future needs of its economy, taking into account programs to develop the industrial sector, ensure import substitution and return domestic enterprises to technological leadership. $66 \%$ of technical schools and colleges in the Sverdlovsk region are involved in the implementation of the Urals Engineering School project. The amount of spending on the implementation of the Urals Engineering School project specifically for secondary vocational education is increasing annually: in the budget for 2018 - 90.2 million rubles, for 2019 - 317.5 million rubles, for 2020 - 385.0 million rubles. Expenditure is made in the form of subsidies to vocational training organizations participating in the implementation of this project, for the organization of activities to develop the material and technical base, for the development and distribution in the secondary vocational education system of new educational technologies and forms of advanced vocational training (including co-financing from the federal budget).

The regional budget is used to finance state programs such as "The Development of Healthcare in the Sverdlovsk Region until 2024" [22], "Development of Culture in the Sverdlovsk Region until 2024" [23], "Development of Physical Culture and Sports in the Sverdlovsk Region until 2024" [24], "Social Support and Social Services in the Sverdlovsk Region until 2024" [25].

There are over 100 educational organizations in the Sverdlovsk Region's system of supplementary vocational training, professional retraining and internships, including: organizations of supplementary vocational education within universities (institutes, departments, continuing education centers); organizations implementing supplementary adult education programs (centers, associations); organizations whose licenses provide for the implementation of supplementary education programs in the region. The largest state program in terms of funding in this area of expenditure is the Sverdlovsk Region state program "Development of the Education System and Implementation of Youth Policy in 
the Sverdlovsk Oblast until 2025", which provides funding for the provision of additional professional education in state educational organizations, as well as the development of content, forms, methods of improving the personnel potential of teachers and specialists in the study of the Russian language (as native, as non-native, as foreign language), development of the personnel potential of teachers in the study of the Russian language, improving the quality of education in schools with low learning outcomes and in schools operating in disadvantaged social conditions, through the implementation of regional projects and dissemination of their results.

It should also be noted that throughout the period under review there has been financing of professional training, retraining and advanced training of public civil servants of the Sverdlovsk Region, municipal servants and persons holding municipal offices. These expenditures are consolidated under the Sverdlovsk Region state program "Development of Personnel Policy in the System of State and Municipal Administration of the Sverdlovsk Oblast until 2024" [26].

The Sverdlovsk Region has approved an Education Development Strategy until 2035 [27], which aims to ensure high quality and accessibility of education that meets social and public, personal educational needs and provides the Sverdlovsk Region economy with qualified human resources.

\section{Conclusions}

Prospective directions for the development of vocational education and training, which will be based on the strategic objectives set, are as follows:

- increasing the level of professional training of pedagogical staff and heads of additional and professional education;

- development and introduction of new systems of incentives and motivation for teaching staff;

- modernization and creation of material and technical basis for the implementation of educational programs in the field of additional and professional education

- creation of a modern and safe digital educational environment;

- ensuring equality in the provision of educational services;

- development of processes (or conditions) of individualization of education (implementation of secondary vocational education programs based on individual curricula) - creation of a balanced system of evaluation procedures at all levels of education based on Russian and international standards;

- ensuring a sustainable relationship between the current needs and labor market development forecasts of the Sverdlovsk region in competencies and qualifications of working-age citizens with the system of vocational education and training;

- creating conditions for people aged 25 to 65 to adapt to changes in the labor market.

The mechanisms for the implementation of the strategy are the implementation of activities and the achievement of the targets of state programmes and projects, which entail appropriate financial support.

\section{References}

1. E. V. Bolgova, M. V. Kurnikova Modeling the spatial organization of the higher education system in the regional economy. Contributions to Economics. 43 (2019)

2. A.A. Tonzherakova Formation of the program for the development of the regional system of professional education as a tool for implementing socio-economic strategy: dissertation kand. ekonom. sci. Barnaul. 13 (2014) 
3. G.N. Lishchina, Realization of Integrity Mechanism in the Regional System of Professional Education Development. Kazan Pedagogical Journal. 2. 101 (2015)

4. D.G. Setalov, Regional market of higher professional education services as a system. Economics of Education. 2. 9 (2007)

5. V.V. Miroshnichenko, General trends in the development of the regional education system. Red.Rev. 2 (2). 13 (2013)

6. N.A. Dmitriev, L.A. Konstantinova, Regional education system and management of its development on the basis of program-targeted model. Proceedings of Tula State University. Humanities. 4-2. 65 (2014)

7. G.K. Lapushinskaya, Formation of the system for planning the development of territorial complex of professional education in the conditions of market transformation of the social sphere: dissertation Doctor of Economics: 08.00.05. Saint Petersburg. (2004)

8. E.B.Dvoryadkina, E.G. Efimova, Regional system of professional education: concept and essence (on the example of an industrial region). Regional Economics and Management: electronic scientific journal. 3(55). 13 (2018) I Internet access : https://eee-region.ru/article/5513

9. On Approval of the State Program of the Russian Federation "Development of Education" : Decree of the Government of the Russian Federation of 26.12.2017 No. 1642

10. Strategy for Development of the System of Workforce Training and Applied Qualifications Formation in the Russian Federation for the Period until 2020 (approved by the Collegium of the Ministry of Education and Science of Russia, Minutes No. PK-5vn dated 18.06.2013)

11. On approval of a set of measures aimed at improving the system of secondary vocational education for 2015-2020: Order of the Government of the Russian Federation of 03.03.2015, No. 349-r

12. On the National Security Strategy of the Russian Federation: Presidential Decree No. 683 of 31.12.2015.

13. 13. On the Federal Target Program of Education Development for 2016-2020: Russian Federation Government Decree No. 497 of 23 May 2015.

14. V.Curran, D. L. Gustafson, K. Simmons et al, Adult learners' perceptions of selfdirected learning and digital technology usage in continuing professional education: An update for the digital age. Journal of Adult and Continuing Education. 25(1). 74 (2019)

15. E. B. Dvoriadkina, E. G. Efimova, Regional system of professional education in the information society. Advances in Social Science, Education and Humanities Research. 240 (2nd International Scientific Conference on New Industrialization: Global, National, Regional Dimension). 708 (2018)

16. A. R. M. de. Oliveira, C. M. Escott Professional education: Current policies targeting the qualification of vocational education in Brazil [Políticas públicas e o ensino profissional no Brasil]. Ensaio. 2015. 23(88). 717 (2015)

17. On Approval of the Strategy for Innovative Development of the Russian Federation until 2020: Decree of the Government of the Russian Federation No. 2227-r of 08.12.2011.

18. On Implementation of Strategic Academic Leadership Program "Priority-2030": Russian Federation Government Decree No. 3697-r of 31.12.2020

19. Main results of the Ministry of Education and Youth Policy of Sverdlovsk region in 2019 and tasks for 2020: Report of the Ministry of Education and Youth Policy of Sverdlovsk region. Ekaterinburg, 2020. Internet access: 
https://minobraz.egov66.ru/uploads/document/2023/doklad-osnovnye-itogideyatelnosti-ministerstva-v-2019-godu-i-zadachi-na-2020-god.pdf

20. Methodological recommendations on providing financial and personnel conditions for the implementation of educational programs of secondary vocational education in accordance with the new model of the federal state educational standard for the 50 most demanded and promising professions and specialties: Letter of the Ministry of Education and Science of Russia from 27.02.2018 №06-341

21. A.A. Korableva, Problems of financing SPE institutions in the regions in modern conditions. Vestnik of Samara State University of Economics. 10(180). 49 (2019)

22. On Approval of the State Program of the Sverdlovsk Region "Development of Healthcare of the Sverdlovsk Region until 2024: Decree of the Government of the Sverdlovsk Region of 21.10.2013 No. 1267-PP.

23. On approval of the Sverdlovsk Region State Program "Development of Culture in the Sverdlovsk Region until 2024": Decree of the Sverdlovsk Region Government of 21.10.2013 No. 1268-PP

24. On approval of the Sverdlovsk Region State Program "Development of Physical Culture and Sports in the Sverdlovsk Region until 2024": Decree of the Sverdlovsk Region Government of 29.10.2013 No. 1332-PP

25. On Approval of the Sverdlovsk Region State Program "Social Support and Social Services to Population of the Sverdlovsk Region": Sverdlovsk Oblast Government Resolution No. 480-PP of 05.07.2017.

26. On approval of the Sverdlovsk Region State Program "Development of Personnel Policy in the Sverdlovsk Region State and Municipal Administration System until 2024": Sverdlovsk Region Government Resolution No. 1276-PP of 21.10.2013

27. On Approval of the Education Development Strategy in the Sverdlovsk Region for the Period up to 2035: Decree of the Sverdlovsk Region Government No. 588-PP dated 18.09.2019 